\title{
Memoria, ¿un concepto multidimensional estratégico?
}

En el presente número, Academia XXII explora en su sección temática la multidimensionalidad de la memoria como una herramienta cultural estratégica en la invención, desarrollo y control de valores socioculturales, geopolíticas del poder y discurso.

Preguntas anfitrionas como qué papel estratégico juega la memoria en la reorientación de la ciencia y de la tecnología hacia la sostenibilidad medioambiental; cuáles son los límites del discurso científico social sobre la memoria cuando se construye como concepto, materia, proceso e imaginario al interior de los nichos académicos, o quién tienen el derecho de nombrar (le) en virtud de la consolidación geopolítica de valores institucionales y colectivos, han estimulado una reflexión interdisciplinaria que revela preocupaciones compartidas y propuestas estratégicas múltiples.

La construcción de memoria, así como la naturalización de valores colectivos constituidos en y a partir de ésta, es inherente al proceso identitario de comunidades y geopolíticas modernas imaginadas. Es así que el lector reconocerá en la evocación histórica, en la selección de registros documentales y en la propia reproducción física de imaginarios y discurso, la prerrogativa política instrumental de nombrar y organizar mundo, además de sus consecuencias. Del análisis de un proyecto socialista de corte indigenista en el Yucatán de los años veinte o del proceso contemporáneo de legitimación de archivos franceses de arquitectura, a la crítica puntual sobre la responsabilidad institucional en el impacto del reciente sismo del 19 de septiembre, se somete a análisis la interrelación entre la invención de espacio, su registro y la consolidación del discurso.

A su vez, en este número se piensa en la fortaleza del ensamblaje cultural "memoria y conocimiento constructivo tradicional" como un fenómeno ético-tecnológico fundamental no sólo inherente a los pueblos originarios de nuestro país, sino necesaria en toda propuesta de habitar material e inmaterial adecuada para un crecimiento sostenible. Este ensamblaje nos plantea la urgencia de una revisión positiva sobre la eficacia 
estratégica de los valores, saberes populares, creencias y pertenencias en el hacer colectivo. Un hacer que también se cuestiona en las fronteras de la conceptualización de las ciencias sociales, sus imaginarios y nichos discursivos en los que memoria y lugar formulan geometrías del poder, así como la propia incógnita sobre la naturaleza de la memoria de lo individual y lo social.

En otro registro de interés, en este número se presentan artículos de investigación sobre el reconocimiento de valores sociales y su papel en la reproducción industrial de objetos, espacialidad y discurso; así como avances de investigación en diseño de valuación de impacto de productos industriales y de modelos de análisis psico-ambiental en torno a la promoción del bienestar. Todo ello ofrece una serie de ideas para pensar la memoria como un concepto multidimensional.

Ciudad Universitaria, diciembre 2017 Johanna Lozoya

\section{Memory, a strategic multidimensional concept?}

In this issue, Academia XXII explores the multidimensionality of memory as a strategic cultural instrument related to the invention, development and control of sociocultural values, geopolitical power and discourse.

Some host questions such as, what strategic role does memory play in reorienting science and technology towards environmental sustainability; what are the limits of social scientific discourse on memory when it is constructed as a concept, matter, process and imaginaries within academic niches, or who has the right to name institutional and collective values, encouraged interdisciplinary thinking, revealing its shared concerns and multiple strategic proposals.

Construction of memory, as well as the naturalization of its collective values, is part of the dasein process of identity and imagined modern communities and geopolitics. Thus, the reader will recognize in the historical evocation, in the selection of documentary records and in the physical reproduction of imaginaries and discourse, the instrumental political prerogative of naming and organizing the world, and its consequences. From the analysis of an indigenist socialist project in Yucatan in the 1920s or from the constitution of a project for a French archive of architecture, to the timely critique on institutional responsibility in the impact of disaster of September 19, 2017 earthquake, this issue submits to analysis the interrelation between the invention of space, its recording and discourse consolidation.

In turn, the strength of the cultural assembly "memory and traditional constructive knowledge" is analyzed as a fundamental ethical-technological phenomenon, not only as constituent of Mexican original communities' approach to inhabiting space, but as a possibility to rethink contemporary and future sustainable, scientific, growth scientific policies and technologies. A posi- 
tive review of strategic efficacy of values, popular knowledge, beliefs and belongings in collective action, is urgent. Thus, to question the limits of social science's concepts for memory, their imaginaries and discursive niches as they are related to place and the way they form the geometries of power, is to confront us to the general incognito about nature and links between individual and social memory.

In a different set of thematic interests, but nevertheless in counterpoint to the phenomena of cultural value's impact in society, two research articles deal with the recognition of social values and their role in urban reproduction, spatiality and discourse. Based on ongoing research advances on design and impact valuation and psycho-environmental analysis of industrial product's modelling on public space and urban well-being, this issue offers a broad spectrum of ideas to rethink memory as a multidimensional strategic concept.

Ciudad Universitaria, December 2017 Johanna Lozoya 